\title{
Practical Usability Problems in Business Economics
}

\author{
Illés Mária \\ Department of Business Economics, Faculty of Economics, University of Miskolc, Hungary
}

Copyright $\odot 2016$ by authors, all rights reserved. Authors agree that this article remains permanently open access under the terms of the Creative Commons Attribution License 4.0 International License

\begin{abstract}
The practical usability of research results is a special advisory function of business economics. Of great importance is in teaching the science-based business knowledge as well. The paper presents the main problems related to practical usability of business economics summarizing more than four decades of research results of the author on this aspect. The examined disciplinary problems are the questions of terminology, some mechanical takeovers from microeconomic topics, some financial decision-making recommendations based on so methodology which does not fit for actual practice, and finally scientifically unresolved issues originating within business economics. Among the latter are: some unclear relations of profitability indicators, product ranking by contribution margin ratios, problematic return requirement sharing for products by cost or price proportions, cost-related cross-sectional analysis and some methodological problems of project evaluation. Clarifying these questions is fundamental for professional education. This is also important for business economists and in particular small and medium-sized enterprises, since their opportunities for in-depth methodological research are very limited.
\end{abstract}

Keywords Business Economics, Profitability Ratios, Return Requirements, Quality Level of Business Activities, Ranking

\section{Introduction}

The disciplinary placement of business economics is not uniform. There is a classification according to which the business economics is a kind of subdivisions of economics. More precisely it is some sort of integration of economic theory and business practice. These publications occur primarily in English-language literature and the origin of this classification dates back to the middle of the last century. In this time the business economics was a young discipline. The usually cited standard work is the book of Spencer and Siegelman [44] from 1959. A significant part of may be listed here publications are tacitly take this direction (e. g. [16]).
According to the main share of classifications the business economics is an independent discipline. Basically this is typical in business economics literature of Continental Europe. The book of Du Plessis et al [9] points out that the business economics became an independent discipline in the 1920s. This book also presents the long development process of independent discipline becoming. According to this, mainly the high-level cultivation of this scientific area by researchers in Germany and the Netherlands resulted that the business economics become an independent scientific discipline. The present paper deals with business economics as an independent scientific discipline.

The central topic of this discipline is the corporation, but does not examine it in its whole complexity. Business economics examines the corporation from an economic point of view, focusing on corporate operations, growth and its interactions with the economic environment furthermore laws of corporate behavior. The two main scientific trends of this discipline are the descriptive and the normative school of thought.

The research method of the descriptive school of thought is basic research. Both the starting point of the research and the theoretical conclusions rely on real-life situations and facts. Descriptive science is also termed a factual science because it examines facts, explores and describes relationships, regularities and rules that operate in reality. In this area, one of the most important and most labor-intensive tasks is the exploration of corporate economic behavior regularities. The research results of the descriptive school of thought enable companies to gain a better knowing and understanding of the economic reality. In my opinion in this area the basic errors, which could cause confusion during the economic activity are not typical.

The normative school of thought is based on a decision-oriented approach. The research in this sphere is essentially applied research. It aims to develop the most appropriate forms, methods and procedures for the corporate management. The research deals with elaboration of the most appropriate methods, forms; threshold limits, norms, and examines conditions needed for fulfillment of thresholds and norms. Moreover, the research examines business decisions and their relationships with the success of business activities. Management-methodology and decision-making 
methods also have a large weight in these areas of research. (Schmalen [42] determines the key issues of business economics according to the different structure. However, the content of this is no different in substance.)

The normative approach gives companies scientifically based advice on and guidelines for the complex context of decision-making processes. The terminology complies with the terminology used in practice, and the level of abstraction is low. Consequently, a significant proportion of research results can be directly applied or slightly modified to suit to the characteristics of the company $[21,34]$.

In business economics publications, there is no sharp line between the two schools of thought. In the above-mentioned topics, business economics has a multi-dimensional internal structure. Each dimension may be further divided into several specific sub-areas where many specific and independent problem areas may occur, that are worth to examine.

My research has been dealing with overall questions and various sub-areas of business economics for more than four decades. The researched subject area is quite wide. Among the processed topics are methodological questions with a large weight as follows: methodological analysis, elaboration of methodological recommendations, model editing and model analysis, and examination of various mathematical formulas of this field. The comprehensive analyses and processing the literature have often brought methodological problems to the surface, which have led to mistakes in education and advisory functions of business economics. Wrong methodical solutions that are appearing in the literature as recommended methods adversely affect the standard of education and the practical application of these may cause serious damages in the corporate management.

The essential aim of this paper is to overview the main methodological disturbing effects of business economics on education and advisory functions. Presentation of the summarized problems highlights the pitfalls, and urges the business economics science for action. The overview is basically uses my own research results. In the analyses the practical usability issues are included and no the actual practical utilization. Achieving the essential aim is a very specific task, since a wide range of research activities belongs to this topic. Considering the summary character of this paper the cited sources are restricted. The compressed versions of proof procedures of the most important questions are included in the appendices. ([30] deals with a more compact presentation of these problems.)

In the context of different topics and different wordings, a great number of papers note the importance of practical usability of the given business economics finding (e. g. [13, 3, 42]). However, a comprehensive analysis of the advisory function fulfillment has not been carried out.

\section{Advisory Function of Business Economics}

Corporate professionals gain a part of their knowledge from the literature. This is true for professionals working in the management field, where business economics plays an important role for three reasons. It:

- provides information and self-education opportunities - one of the sources of life-long learning,

- offers advice and guidance at a general level,

- is a link between corporate professionals and corporate advisors.

In the point of view of direct utilization, the most important is the advisory role. The business economics literature often mentions the importance of the professional clarity and practical implications of the suggested methodology. That is, the majority of the business experts can only apply the methodology correctly if they can fit methods to their way of thinking, and if they can somehow connect them to the logic of the economic process.

From the early 1900s, over the last century, there were business professionals writing academic-based books and papers in areas of business economics, and they were considered high-level researchers as well. Presumably, at that time it was a matter of prestige for the company to have professional teams that were known in and acknowledged by professional circles. However, over the past few years corporate professionals have produced substantially fewer high quality theoretical and methodological publications than earlier. They take part in academic forums mainly for purposes of marketing and relationship building. Probably the scientific achievements of corporate professionals also have become a competitiveness factor within companies [25].

In the publication practices of economic consulting firms, the main target is to raise awareness of the firm and to strengthen its reputation for advanced professionalism. Economic problem-solving methods and techniques that can be reconstructed in practice are missing from publication palette of these companies. In their case, a special methodological knowledge is fundamental in terms of competitiveness. If this knowledge were made public, the demand for their consultancy services would decrease.

After the turn of the millennium research results in business economics areas are published primarily by research institutes, universities, professional institutions and interest representative bodies. Published high-ranking research results indicate that there is a kind of institutional knowledge, which in some cases even may serve as a condition for the survival of these organizations.

Now, in the middle of the $2010 \mathrm{~s}$, the advisory role of business economics is far from being perfect. The practical usability of the discipline is problematic in several cases because of terminology problems, some mechanical takeovers from microeconomic topics, financial 
recommendations based on methodology unsuitable in practice, and finally the scientifically unresolved issues within the area of business economics. The clarification of these problems is also important from educational aspect.

\section{Terminology}

The knowledge of terminology is a basic criterion for acquiring and practicing all occupations. However, the scientific terminology and practical conceptual usage may differ. This relationship differs by specialization. The existence of clear categories, which are evident for practice, and the exact use of terms are crucial in several academic fields. The proximity to the practice of terminology is especially important in those areas where the discipline wishes to directly support everyday professional activity. It is obvious that there are field differences even from this point of view. An artificial language of science, for example, is probably useful for the medical community, but it will be detrimental to the area of business economics. The curative medical activities are taking place in a relatively homogeneous professional community; therefore, the difference between medical terminology and practical wording does not produce disturbing effects. (Patients who cannot follow the medical terminology can suffer greatly from misunderstandings is another matter.) However, practicing economists maintain a daily working relationship with representatives of different special fields. Because of this, in this field a professional language that is completely unrelated to daily wording would hamper the practical application of research results.

The business economics terminology is practice-oriented all over the world. However, sometimes this terminology is very loose. Some category names cover several kinds of economic content; likewise, there may be specific content that is used with different category names, also. The disturbing effect of these may be reduced to a minimum with appropriate professional knowledge, using coherent context and careful explanations (and examples). During the overall developing process, some functional subfields of business economics have become independent basically, or partly intertwined with other disciplines. Because of this, the different parts of business economics have become richer, with some dissimilar disciplinary characteristics and categories (as in the case of human resource management or marketing). This general trend in itself does not create disturbing effects. However, not all of the sub-categories of functional areas have been selected carefully. In these cases, the terminology makes the business economics somewhat fragmentary, and can disturb the clarity of comprehensive research. As for the functional subfields in the mid-2010s, the most significant terminological differences are experienced in accounting and finance.

A remarkable source of confusion is generated when categories of the same name have different economic content in different disciplines. As is well known, one source of misunderstandings is that certain basic category names of business economics and microeconomics are the same, but the economic content behind the same category name is different. The most typical examples are as follows: cost, cost function, profit and break-even point.

Microeconomics, in accordance with its own scientific objectives, considers opportunity costs as a part of factual costs, and furthermore implements most of its analyses by applying U-shaped cost curves. (These curves have very special model conditions, which are not always shown.)

In microeconomics, basically, the cost curves are heuristic and serve demonstrative purposes. They are not calculated from factual cost processes and cannot be considered to be generalized variants of factual cost functions (although they reflect well the most general content correlations). The disturbing effects of categories with identical names but different content can appear at the higher education level, as well. In my own teaching, I have experienced has been that a significant proportion of the graduating economics students routinely and incorrectly portrayed a U-shaped cost curve instead of practical unit cost function. The fair drafting possibility of U-shaped cost curves is very much doubtful in practice. (See Appendix No. 1.) Moreover, in practice the cost function contains solely real costs. The practical cost items are all in real costs, and behind them, there are always factual expenditures. In practice, the cost does not include opportunity costs [18].

The classical contribution margin diagram is one of the most widely used models in business economics. The diagram presents the cost recovery and profit formation process of the production volume as a function. In business economics, the classical break-even point is the intersection of the cost function and the revenue function. In microeconomics, the break-even point is a less important topic; a number of microeconomic books make no mention of it (e. g. the book of Ekelund \& Tollison [10] no mentions it, and the book of Samuelson \& Nordhaus [41] included it in about one and a half row in extent). In this discipline, the break-even point indicates also the return point of cost, but the category contents and model conditions are different. The break-even point of the two disciplines has fundamental content differences in cost function and the revenue function; moreover, the illustrative concept is fundamentally different $[21,27]$.

By making a clear demarcation of subject areas of microeconomics and business economics and by communicating which discipline the publication refers to, the unfavorable effect of confusion of categories with different contents can be decreased to the minimum.

\section{Mechanical Takeover of Partial Microeconomics Topics}

Each discipline has relatively independent research fields, research objectives, approaches and category systems. A number of factors determine which scientific item can be 
used in business economics at which concreteness level at what transformation and harmonization demand of microeconomics. It is widely known, for example, that the principle of marginal analysis, the return requirement according to the principle of opportunity cost, and the principle of time value of money have become an integral part of business economics. However, it should be emphasized that only principles and not the scientific theories and examination procedures are incorporated in the toolkit of business economics. Because of the different disciplinary characteristics, usually even the practice-oriented theses of microeconomics cannot be copied into the areas of business economics [21, 34].

Presumably it arises primarily from the previously mentioned characteristics of the disciplinary classification, it has become characteristic that business economics literature published in English takes over scientific theories, models and assumptions from microeconomics and uses them as business economics questions (e.g. [16]). A typical example of this is the above-mentioned U-shaped cost curve. Despite these publications, cost functions that correspond to the format of U-shaped cost curves generally cannot edit (more precisely, it is not worth to edit) it in practice, and they are not applicable in business economics. They are usually suitable only as a heuristic approach to shaping attitudes. (See Appendix No. 1.) Taking over isoquant and isocost analysis is similar to this problem. Namely, these models assume that production factors are arbitrarily divisible and combinable in all ratios. However, these relationships cannot be quantified for actual company data and such sort of information is not usable for profit-based decision-making. Theoretically, of course, the question is interesting, but only theoretically. The concept of microeconomic models as business economics problems differs from the objectives and the methodological basis and category system of business economics and hinders the development of the advisory function of the discipline [34]. (According to Do Plessis et al. [9] the approach of business economics in the USA is theoretical however this theory is macro-economic. This approach does not reflect the viewpoints of business economics researchers.)

It should be noted that microeconomics does not have an economic advisory function and does not strive for it. Theories and models of microeconomics that are not in accordance with corporate conditions are confusing if they are taken over by business economics. The book of Kaplan \& Atkinson [35] mentions a disadvantaged solution that the microeconomics principle of "price is equal to marginal cost" was applied in practice.

\section{Financial Recommendations Confusing for Corporations}

Serious methodological contradictions are generated when the different disciplinary foundations are used to solve the same problem. Finance, namely, is based on standard microeconomics, or as Volkman says "based on orthodox economic theory" [47]:75. Problems caused by microeconomic roots are mentioned also by Woods and Randall [50]. The microeconomics is not a business practice oriented science. The finance does not take this into account. There is a significant difference between the theorems of finance and business economics as far as the proximity to real-life problems is concerned. Basically there is no direct passage within microeconomics and business economics because of the very different abstraction level, different category system and different approach. Walker et al. [48] give a detailed description of teaching completely controversial materials about IRR and NPV. (The description is in conjunction with the problems of reinvestment rate assumptions.)

There are several practical contradictions between proposed methods by finance and business economics. This contradiction has an unfavorable effect on the advisory function of business economics. The business professional cannot decide which variant is true. Functional sub-areas of corporate management include financial management as well, which forms an integral part of business economics in this context. However, the literature of corporate financial management largely has become independent from business economics and become some kind of descendant of finance. The source of the problem is that the finance is built on a microeconomics basis, so its scientific methodology is not usable in real practice. This situation results the content contradictions in statements and methodology recommendations between business economics and finance. However, the disturbing effects are not rooted in microeconomics, but in recommendations to companies arising from this.

Contrary to microeconomics, finance provides practical guidance to companies. In finance, the abstraction level in recommended methods is high; moreover, the model conditions are not always clear. In concerning methodological questions the finance findings and conclusions are based on two general assumptions: the investment opportunities are unlimited, that is the financial resources can be arbitrary expanded furthermore the reinvestment rate is equal to the required rate of return. (Although these assumptions are regularly behind the finance models, it is not stated always clearly.) These two conditions are never met in reality at the same time. The practical reality of these assumptions can be discredited on a simple empirical ground as well. It is true that laudable scientific analyses can be carried out even in cases where the level of abstraction is high. However, before such research findings are used in real practice (if it occurs), where the assumptions are not met in economic reality the assumptions should be changed and the relationships should be reworked [29].

Pursuant to the above, finance usually does not bring the initial model assumptions close enough to terms experienced in real life when formulating recommendations for companies. Major problematic consequences of this 
particularity are as follows: giving priority to NPV as a superior method; recommending the NPV for ranking compilation; interpretation of the NPV as being the same as the shareholder value of the project; decreased yield requirement for debt; interpreting interest payment as a tax shield; presenting some clear business management relationships in a confused financial way (for instance, equivalent annual cost). These problematic topics are described in further parts of this chapter.

\subsection{The Content of Net Present Value and Its Suitability for Ranking}

The finance literature definitely prefers the NPV (or its derived indices) for economic evaluation and for ranking of projects. The recommendation is quite mechanical. There are no strong and methodically supported arguments to demonstrate the primacy of the NPV over the IRR. It does not define the economic content of the NPV, and does not deal with the logical relations of the calculation, either. (Similarly, these issues are not dealt with in business economics.)

According to Volkman's [47] research, the emergence of contradiction in method rating could be attributed to the fact that finance propagates the more advantageous nature of NPV method based on one of the Fisher's works [12] published in the first half of the past century while business economists (and business professionals) prefer the IRR method based primarily on the works of Boehm-Bawerk [5] and Keynes [37].

The NPV curve is well known. The general context of it is that the NPV gradually decreases due to the increase in interest rates, and then it switches to the negative sign. However, it can be proved that this model is only true for profitable projects with orthodox cash flow patterns. Another important relation is that in the case of a zero interest rate the NPV is in fact the nominal accounting profit generated during the whole duration of the project. Substituting the zero interest rate in the basic formula, the NPV will be the difference between the nominal value of all revenue and the nominal value of all expenditure. (See Appendix No. 2.) Therefore, only the nominal profit sum generated during the whole duration can be used to cover the required profit according to the required rate of return. The present value of the remainder sum is the NPV itself. Thus, the NPV with a positive sign substantively is the discounted sum of the surplus profit resulting above the profit requirement. This relationship can be proved in an itemized way in addition to various resolutions. (See Appendix No. 3.)

The NPV despite the related recommendations is inherently unsuitable for ranking of investment projects. This is because the NPVs cannot be compared. The differences in initial investments, the durations and the rapidity of capital returns may distort the comparability of NPVs. (Although these relations were recognized in the 1970s [36], a clear consensus even today is still missing. To the best of my knowledge, aspirations of eliminating these distortions through a complex correction have not been occurred in other publications so far.) During the systematic elimination of distorting factors, the NPV transforms into a kind of surplus rate, namely the difference of the internal rate of return and the required rate of return. (See Appendix No. 4.) The ranking according to this rate difference - with the same required rate of return - equals the ranking based on the internal rate of return. If the risk levels of the examined projects are different, prior risk management to ensure comparability can significantly decrease its disturbing effect (e.g. through correction of revenue or expenditure lines). Therefore, the internal rate of return, or with the same results the profitability surplus rate, are primarily suitable for ranking. So the NPV and pure corrected variants of it are not suitable for ranking [28]. NPV is only suitable for the economic evaluation in the case of projects with orthodox cash flow patterns. (The wording of this relationship is in [24], the proof is in [33].)

\subsection{Using Net Present Value as the Shareholder Value of The Project}

Among the advantages of NPV, finance literature regularly mentions the theorem according to which the NPV indicates the project's contribution to the shareholder value (e.g. $[7,46])$. The publications often refer to Fisher's related theorem. There are also a considerable number of authors who interpret the NPV primarily or simultaneously as the surplus of company (or firm) value ([36, 4, 38]. However, in the reality (as it is well known) the shareholder value is not equal with the firm value (the difference is the sum of debt), and the maximization of the firm value is not the same as the maximization of shareholder value.

Starting from the above finance frequently states that the NPV is superior compared to other efficiency indexes because its sum quantifies the contribution of the project to the shareholder value as well. The paper of Woods \& Randall [50] says that the direct relationship of NPV and shareholder wealth has never been proven. From the disputable and never proven statement, finance draws the conclusion that the decision made according to the order of the NPV sums leads to the maximization of the shareholder value. However, it can be proved that the maximization target according to the above-mentioned theory can only be realized if the access to capital is unlimited and the reinvestment rate is equal to the required rate of return. In reality, there are no conditions like that. The possibility of capital expansion is not unlimited for companies, and profitability opportunities of reinvestments are different from the required rate of return. In reality, ranking according to the NPV - due to the distorting factors mentioned above generally does not lead to the long-term maximization of profit, nor to the maximization of the shareholder value. (See Appendix No. 4.) The theorem is alive today as well, even though it cannot be proven moreover it contains many logical contradictions. 


\subsection{Specific Interpretation of the Yield Requirement of Debt}

One of the basic tenets of finance is that the required rate of return is chargeable only to the equity, and debt yield is sufficient, if the interest payment will return (because the debt owner expects only this return). This approach is problematic. Firstly, this basic principle does not harmonize with microeconomic principles, and secondly, nor does it fit in with economic realities either. When microeconomics defines opportunity cost regarding investment opportunities, it does not draw a distinction between the equity and the debt. There the capital is an unstructured amount and the unstructured opportunity cost concerns the whole capital. According to economic realities, the market prices of goods are not affected by what type of capital ownership structure stands behind the production, therefore the EBIT (that is earnings before interest and taxes) requirement calculated in accordance with profit requirement cannot depend on the capital composition.

This differentiated yield requirement does not take into account that the market risk concerns the amount of the debt as well, and the risk taker of this firstly is the equity. (See Appendix No. 6.) As compensation for market risk-taking, a risk premium concerning the debt should also be returned to the borrower. The economic content of this is profit requirement. Consequently, the required risk premium ratethe difference between the required rate of return and the interest rate - must be charged to the debt. (In this case, the yield requirements of the equity and the debt become identical.) If the profit is equal to the equity multiplied by required rate of return, but no more and regarding the debt return only by the interest payments, then the return requirement based on the principle of opportunity cost is not realized, and the activity is uneconomical. The examined financial axiom probably applies a tacit assumption that the owner of the equity is not in the position to realize that more debt is a greater market risk on a unit of equity. However, in relation to this axiom there are further interesting and important relations as well. The concept of lowered return requirement level concerning the debt, on the one hand helps the capital placement of banks and this is an advantage for banks, on the other hand lowers the required profitability level that is a norm of managers. (The lower requirements can be met more easily.) However, this is a disadvantage for the equity owners $[18,19,24]$.

The two main variants of yield requirement differentiation are as follows: the valuation method through automatic yield differentiation, and the WACC (weighted average cost of capital). The first variant applies an absolute type of cash flow calculation where the debt entering is not a part of investment, but is considered revenue. The repayment of debt and its interest payments appear among the expenditures in the future. As the entering debt does not appear as a part of the investment, the difference between the required rate of return and the interest rate cannot even be taken into account. The WACC as a second variant of yield differentiation contains differentiated yield requirements in direct way. The weighting is created according to the average capital structure of the company. The WACC has appeared also in business economics publications (e. g. [3] ).

Nowadays, there are finance studies that consider the clarification of the relationship with the practice as their goal. Clear views can also be found among them. For example "The WACC is neither a cost nor a required return: it is a weighted average of a cost and a required return. To refer to the WACC as the »cost of capital« can be misleading because it is not a cost" [11]:9. It is a source of numerous misinterpretations that finance - just like microeconomics calls the return requirements arising according to the opportunity cost as simple cost as well. In practice, however, only those items are called costs behind which there was, is or will be some expense. (Certain fields of business economics have partly adopted the cost-interpretation of microeconomics; however this does not become disturbing in a proper context.)

\subsection{Interest Payment as a "Tax Shield"}

In reality, the main advantage of borrowing is the implementation of the necessary resource access, and the main disadvantage is the obligation of interest payment.

However, finance interprets the interest payment as a possibility that provides a tax advantage. The name of this is the tax shield [6]. This approach is misleading. The interest is not paid from the income tax. The interest payment decreases the potential sum of the before- tax profit, and due to this income tax decreases. It is an essential relation that not only the sum of the tax, but also the after-tax profit is decreased. If the tax rate does not reach $50 \%$, the potential after-tax profit decreases largely than the income tax. (For example, when the tax rate is $24 \%$ and the interest payment is 100 units, then the structure of decreasing is as follows: profit-tax amount decreases by 24 units, after-tax profit decreases by 76 units.) If the interest payment is high enough, then the amount of profit tax is reduced to zero and the after-tax profit will also be zero. What kind of tax protection is this? In this relation, a lower profit tax is no advantage at all. (A further disadvantage of the high debt is that this increases the risk of the equity. Moreover, the growth of indebtedness can reduce the independence of corporate decision-making.) The definition of credit interest as a tax shield can create false ideas. In my experience, the distorting effect of this approach is significant mostly among the students [22].

\subsection{Equivalent Annual Cost}

Equivalent annual cost is a finance category. Many debatable constructions and interpretations of it can be found in the current finance literature. The occurrence of this phrase is not typical in business economics. Instead of this, two similar, but clear content categories are used as follows: the annual average cost of capital (that is nominal value return plus profit requirement) and the second is the sum of 
the annual average cost of capital and the annual running costs. The latter category plays an important role in the preparation of investment decisions that do not have a clearly measurable yield effect. That is, these methodological solutions should be used when assessing non-productive investments or in the case of the independently manageable elements of investment projects [23].

The equivalent annual cost in most cases serves a similar purpose in finance as the analysis principle of business economics described above. The literature of this, however, is very confusing. For example, it often occurs that the average annual net present value is called equivalent annual cost. Furthermore, the unclear notion of the equivalent annual cost also shows the fact that in this case the required rate of return (independently from the capital structure) appears as the hurdle rate, while the net present value method in finance usually uses the weighted average cost of capital as the hurdle rate. No explanation can be found as to why these hurdle rates are not the same, and even - to the best of my knowledge - the literature does not mention this discrepancy. In addition, as far as I see, this cannot be explained [23].

\section{Faulty Recommendations Originating from the Disciplinary Problems of Business Economics}

Business economics naturally has unsolved questions, and in addition to this it has some long established theorems and recommendations that are unproven, arbitrary and at the same time misleading. Compared to external confusing effects, the scientifically unclear questions of business economics are more important.

\subsection{Some Unclear Relations of Profitability Indicators}

The business economics literature is rather eclectic, as well as indeterminate in the question of the profitability ratio that describes the economic functioning quality of the company in the best way. Depending on the aim of the analysis, many profitability ratios can reasonably be used (with the right knowledge). However, if the profitability ratio is to be used for that purpose of describing the quality of the economic functioning of the company, it should be clear that only ratios could be used for this purpose that are free of systematic distortions. The distortion-free condition is that the indicator can be derived from the total return requirement. (See Appendix No. 7.)

In the case when companies are operating on private capital principle, the static version of the complete return requirement is as follows: the total revenue should be at least as much as the sum of the value of the used up resources and the yield requirements according to the required rate of return. The two basic versions of the ratios, which are derivable from the complete return requirement, are as follows (showing also the threshold value of good economic functioning):

$$
\begin{gathered}
\frac{\text { Profit }+ \text { Interest payments }}{\text { Total capital }} \geq \text { Required rate of return } \\
\frac{\text { Profit }- \text { "Price" of equity usage }}{\text { Total capital }} \geq \text { Required risk premium rate }
\end{gathered}
$$

The fraction in the upper inequality is the index of the classical ROI, which was elaborated in 1914 by Donaldson Brown, the expert of the DuPont company. The other fraction appeared at the beginning of the 1980s in the German literature.

The index of profit ratio on total capital (Profit/Total capital) is often recommended for measuring and comparing. However, this fraction and any reasonable threshold value for this cannot be deduced from the context of the total return requirement. Consequently, this profit ratio is not suitable for measuring economic functioning of the company. Comparing these indices also generates distortions. It can be easily seen that this recommendation does not calculate with the part of capital yield that is the paid interest. Due to this fact, the higher debt results in lowering this sort of profitability rate. Another often-recommended index is the profit ratio on equity (Profit/Equity). This ratio, of course, shows how much profit is produced per unit of equity. This index disregards the fact that the debt also affects the profit sum. In cases where the ROI is lower than the interest rate, the profit decreases by the amount of the debt. If the ROI is higher than the interest rate then the profit will increase by the debt. The profit on equity ratio will vary according to the previous ones as well. (The debt increases also the risk of equity.) The price-related (revenue related) and cost-related profit ratios are not compatible with the driving force of companies operating on capital principle [17, 18].

\subsection{Product Ranking According to Contribution Margin Ratios}

One of the most problematic and misleading methodological recommendations of business economics is the economic ranking methods for the products produced. Among the recommendations in this area, ranking according to contribution margin ratios is given the largest weight. According to recommendations, the classical contribution margin is in the numerator and the price is in the denominator as follows:

$$
\text { Misleading ranking index for products }=\frac{\text { Unit price }- \text { Proportional cost }}{\text { Unit price }}
$$

The "science" does not deal with this methodological question however the using of the method plays a dominant role in the practice and education. For example Garrison puts it as follows: "... the manager will search out those product lines that have the highest contribution margin ratios" [13]:219. In 2014 I myself had the opportunity to get to know a transnational company's product evaluation system. This 
company also uses the contribution margin ratios as a ranking tool.

This sort of ranking method is very problematic in the manufacturing sector. With regard to its purpose there is a significant distortion effect both in the numerator and in the denominator. The nominator problem is as follows: The classic contribution margin is primarily suitable for estimating the impact of production volume change on profit, but not suitable for ranking purposes. When a comparison is performed, it should be taken into consideration that products are requiring also technology costs in different proportions. More advanced technology usually bears higher fixed-cost. The major proportion of technology cost is fix cost. Consequently, some unprofitable product may be hidden behind their greater classic contribution margin.

In the denominator appears the unit price. The price as a benchmark in this context is distorted because the product price and cost ratios are far from being identical to capital requirement ratios. First of all, the capital is wandering in the economy according to the available profit rate. In addition, the product price includes also the cost of materials return. In the manufacturing sector, the raw material cost has the highest weight, reaching $55-85 \%$ of all costs. The material cost proportion is significant and is widely scattered according to products and activity areas. The amount of material cost is highly independent of capital needs. It is obvious that material costs also have capital needs. However, the capital need of material depends on the rotational speed of working capital. The latter also varies greatly because the stockpile management policy and production lead times are very different. Overall, the denominator has a distorted effect because the product cost ratios is far from being the same, as the capital needs ratios.

A remarkable experience: in the 1980s, the share of lease work was unhealthily high in the Hungarian manufacturing industry. A key role in this situation was that the competent authorities strongly recommended to companies the product ranking according to the classic contribution margin rate from the mid-1970s $[17,18]$. (The price of the lease work does not include the return of direct material costs; consequently, the denominator becomes unrealistically small. Due to the effect of the small denominator, the rate of the classic contribution margin may be relatively high even if the lease work is relatively unfavorable.) Some recent publications support product ranking according to the classic contribution margin ratio, while others describe this ranking as a practical method, without professional resolutions or evaluations. Ranking according to the classic contribution margin ratio has a determining weight in business economics books. Substantial methodological critique is not known. Experience has shown that numerous companies apply this ranking worldwide.

In 1985, I worked out an indicator for product economic ranking that does not contain significant distortive effects [17]. In the numerator is the net contribution (Net contribution $=$ Price $-[$ Direct costs + Machine costs and profit requirements of capital invested in machinery, calculated per machine according to the related norm time respectively].) In the denominator is a product-related corporate effort indicator as follows: ([Direct costs + Machine costs and profit requirements of capital invested in machinery, calculated per machine according to the related norm time respectively] - Cost of materials with energy cost). This is slightly more labor intensive than the false solution presented above, but this disadvantage is not significant if the company has an adequate information system and information technology.

\subsection{Price and Cost Proportional Sharing of Burden}

The price or the cost proportional burden sharing is widely applied. This sort of burden sharing may relate to products, divisions, profit centers, etc. In the manufacturing sector, the distorting effect is very similar to the price proportional yield measurement problem described above. Material cost is a passive element from the perspective of value formation and value superposition. The significant distortion is caused by the burden being shared by proportion in factors that include material costs, which have heavy weight and variable ratio. Methodologically, in the manufacturing sector markup pricing also includes the same problem of burden sharing. Furthermore, markup pricing includes another contradiction in that the required yield is capital proportional, while in turn the distribution of it is cost proportional. The context of markup pricing in trade is different from this $[17,18]$.

\subsection{Cross-sectional Analyses Based on Costs}

Cross-sectional analyses dominate cost accounting methods. (A database of cross-sectional examinations concerns a given year.) The almost general characteristic of the applied methodological basis of this is that it does not calculate with the required rate of return (e.g. [43, 40, 45]). That means that in this sphere, the considered return requirements typically are cost return requirements and do not include profit requirements. However, the profit requirements must also be recovered. Higher capital needs lead to a greater profit requirement. The elaboration and publication of appropriate methodological solutions for this requirement is an important task of business economics. (Some proposed methodological solutions can be found in $[17,18,26]$.

The contradictory nature of the discipline itself indicates that while the investment evaluation models always take into account the required rate of return, the cost accounting literature does not take into account the profit requirements, even in the case of comparing technological variants. The cost accounting literature offers quite a different approach for the evaluation of technological variants. For instance, it attempts to seek an answer to the question of how large a production volume is required so that the total annual cost of two technological variants will be equal (e.g. [14, 43], or the profit of the two different technologies will be the same [1]. 
These issues may also be worth examining, but the fact that variants with different capital needs have different profit requirements should not be neglected. Furthermore, the similar profit sum of the examined variants - apart from opportunities for similar capital needs - does not mean equivalence in terms of economic efficiency [26].

\subsection{Methodology of Economic Evaluation of Investment Projects}

Disciplinary problems of investment project evaluation are also present in the field of business economics, in addition to the disturbing methodological recommendations of finance. Further research would be required to identify which problems originate from business economics and which problems are the results of different financial impacts. The most important disciplinary differences are the following: business economics typically does not give priority to the NPV; not considered general acceptance of the differentiated yield requirement; and typically pre-tax profit or EBITDA are used in calculations. (In finance, usually profit after tax and net cash flow are used.)

In this topic, the major business economics tasks are as follows [24]:

Elaboration of content questions of the methodological background;

To fit the basic methods to various practical problem peculiarities;

Elaboration methods for evaluation of unorthodox cash flow pattern (the generally recommended NPV method cannot be applied in this case because of gives false information [24, 33]);

To point out the problematic traits of finance recommendations that are based on model conditions which are far from the reality.

It is advisable to take into account the aggregate capital needs as well. Aggregate capital needs is a new business economics category. Quantification and consideration of this could significantly improve the economic evaluation and comparison of investment projects. The sum of it depends on the initial investment, duration of projects and the rapidity of capital return. This means that amount of capital that is needed for the operation of full duration. The measurement unit of this is one unit tied-up capital for one year. For quantifying, we add up the yearly tied-up capital that is the not-returned part of the capital in certain years. This solution is considered to be correct because the tied-up capital is computed with a database where in the first step the profit requirements are subtracted from the yields of certain years. The remainder is interpreted as a return of capital and reduces the tied up capital of following year. In the case of internal rate of return, the estimation of aggregate capital needs may be greatly simplified. (See Appendix No. 5.) It is interesting to examine how much total capital is used in an investment project, to generate a given NPV and a given IRR. It is favorable if smaller aggregate capital needs result in a higher NPV or greater aggregate capital needs result in a higher IRR. The category of the aggregate capital needs has a significant opinion-forming role. During the decision preparation of investment projects it is advisable to take into account also the aggregate capital needs [32,33].

Additional information for support of decision-making may be the critical profitability rate of capital differences of investment variants and its achieving opportunities [28].

\section{Conclusions}

This paper has given a summary of the main problem groups causing difficulties in the practical usability of business economics. Among these, there are terminology problems, some mechanical takeovers from microeconomic topics, financial recommendations based on methodology that is not suitable in practice, and finally the scientifically unresolved issues originating within business economics. These problems can impair also the efficiency of higher education.

A part of the disturbing effects have emerged from outside. These partially can be reduced with very strong methodological publications. However, experience suggests that finance recommendations based on microeconomic roots and are controversial with business economics in many aspects, presumably will stay for a long time. To improve the possibilities of advisory function effectiveness, business economics must publish its basic principles and scientific items precisely and clearly; furthermore, methodological recommendations need to be proved logically and/or mathematically. The solution of problems emerged inside the disciplinary borders is the shared task of researchers, teachers and practical experts who are working in this field. The comprehensive work of individual researchers may ensure a uniform and consistent approach in different business economics publications. This sort of research plays an important role in the elimination of contradictions, because problematic issues would appear automatically when the research encompasses a wide range of content.

According to the Bologna system of European higher education, the subject of business economics is part of the curriculum in the first year of the bachelor course, which does not help comprehensive and in-depth business economic research. The clarification of problematic methods and explanations would be very important from educational aspect. The more efficient appearance of the advisory function of business economics would be particularly important for small and medium-sized enterprises. In this sphere, professionals should act in a relatively broad management area. Therefore, usually there is not enough available mental capacity for methodological research. A clearer and stronger base in the business economics literature could contribute considerably to the improvement of the competitiveness of this sector. 


\section{Appendices}

\section{Appendix No. 1 - Cost functions in practice}

According to business economics the cost functions can be constructed using real economic data. Theoretically two different cost models can be used when is editing cost functions. These models are as follows: general shaped and linear.

Model conditions of the general shaped cost function are as follows:

1. The factory produces one type product.

2. The capacity is a given size.

3. The upper limit of the range is the technically possible maximum quantity. (That is very broad.)

The general shaped total cost function and its derived functions are shown in Figure 1.The upward stems of the U-shaped cost functions are produced due to the progressive costs effect. The upper limit of the range is at the theoretical maximum of quantity. It means that when the production exceeds the normal capacity level the technology is increasingly plundered. At this stage, any of the cost that is not progressive, may become progressive. Beyond a certain quantity the technology cannot work more.

To my corporate knowledge, in some special situations, enterprises undertake a smaller proportion of progressive cost. However, this occurs rarely and the concerning quantity is relatively low. If they wish to produce permanently more than the permitted normal load requirements of machines, they can expand the capacity. The expanded capacity already has a new cost function. Consequently, there is not practical information, to construct the cost function in the progressive cost zone. This is the reason that cannot be edited a cost function that maps the progressive zone. In principle, these could be edited with enormous financial sacrifices. However, the technology is developing continuously. Consequently, this expensively acquired knowledge could be utilized only in the short term.

The general shaped cost function which is composed on the logical basis (as a heuristic function) can be interpreted as a cubic function. In this case all the average cost function and the marginal cost function is a quadratic that is U-shaped. Despite the formal similarity these U-shaped cost functions basically differ from U-shaped cost curves of microeconomics according to the condition system and the content of costs.

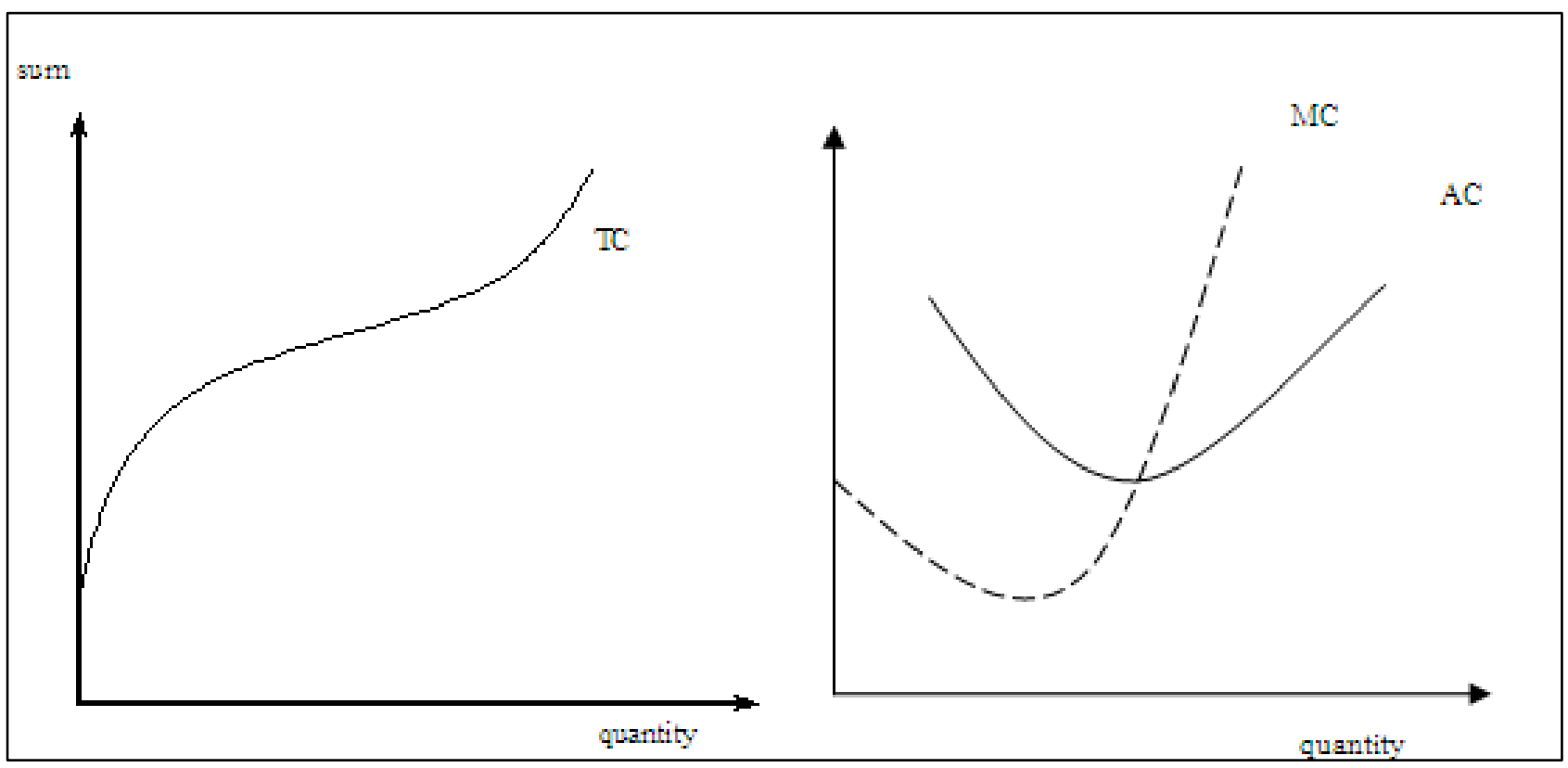

(The list of symbols is in Appendix No. 8.)

Figure 1. The general shaped total cost function and its derived functions in business economics

In practice mainly linear cost function model is used. This model is one of the components of the classical contribution margin diagram as well.

Model conditions of the linear cost function are as follows:

1. The factory produces one type product.

2. The capacity is a given size.

3. The upper limit of the range is the technically permissible maximum load.

The conditions of two models are differing only in the third one. The third condition of the linear cost function model does not allow to taking into account the opportunity of growing technology plundering, and the incurring of substantial progressive costs. The linear total cost function and its derived functions are shown in Figure 2. 


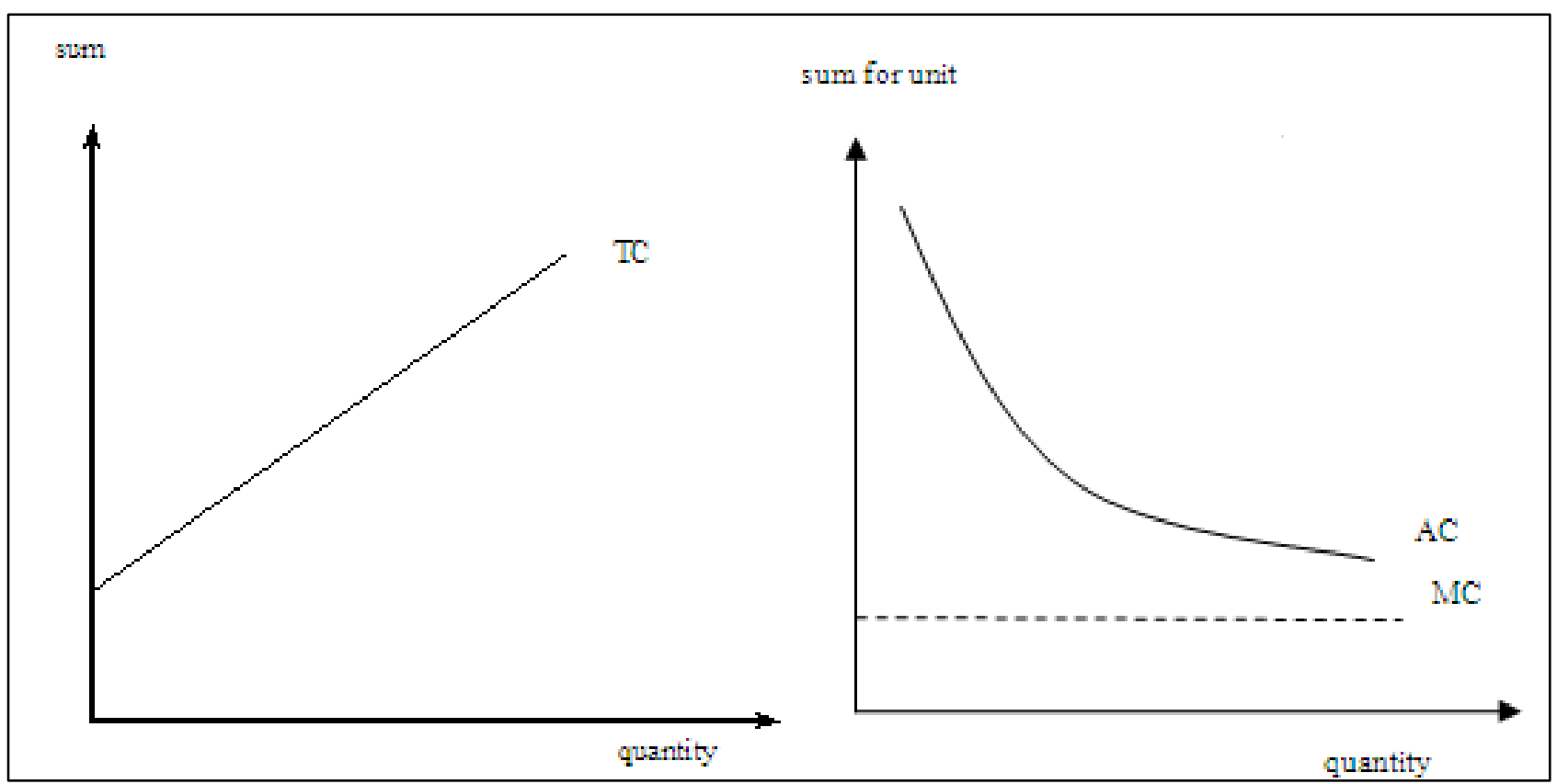

(More details are in [18).

Figure 2. The linear total cost function and its derived functions

\section{Appendix No. 2 - The NPV curve}

In well-known theory, the NPV is calculated so that the discounted sum of all expenditures is subtracted from the discounted sum of sales revenue that is associated with the examined investment project. The calculation can also be made with the time series of the difference of revenues and expenditures. Then the annual differences are discounted and summarized. Hereinafter, in order to simplify modeling, that sort of model will be examined where the payment of initial investment occurs at the same time as operation is started. This is date zero. The first revenues will occur one year later, by this time the annual revenues exceed the annual expenditures. One of the basic formulas of NPV method are used for this problem is as follows:

$$
N P V=\sum_{t=1}^{n}\left(B_{t}-K_{t}\right) \frac{1}{(1+i)^{t}}-E_{0} \quad \mid B_{t}-K_{t}>0
$$

(The list of symbols is in Appendix No. 8.)

The NPV curve is well known (Figure 3). The plotting of this is a regularly appearing topic within the literature of investment projects evaluation. The authors also consider that this figure is well-known and widely used; therefore do not use any professional reference. The figures and related explanations are introduced from different perspectives: once a general theoretical relationship [3], another time as a solution of an exercise or an introduction of a problem through an example $[6,46]$.

Figure 3 shows the NPV curve. By this the higher the interest rate is, the smaller the NPV. As a result of increasing interest rate, this decrease first reaches the zero NPV, then further increasing results in higher and higher negative NPVs. The interest rate that is at the intersection of axis $\mathrm{x}$ and that results in zero NPV is the IRR. (This is well known.) I am aware of no literature sources on the pre-conditions and detailed content background of the illustrated relationship.

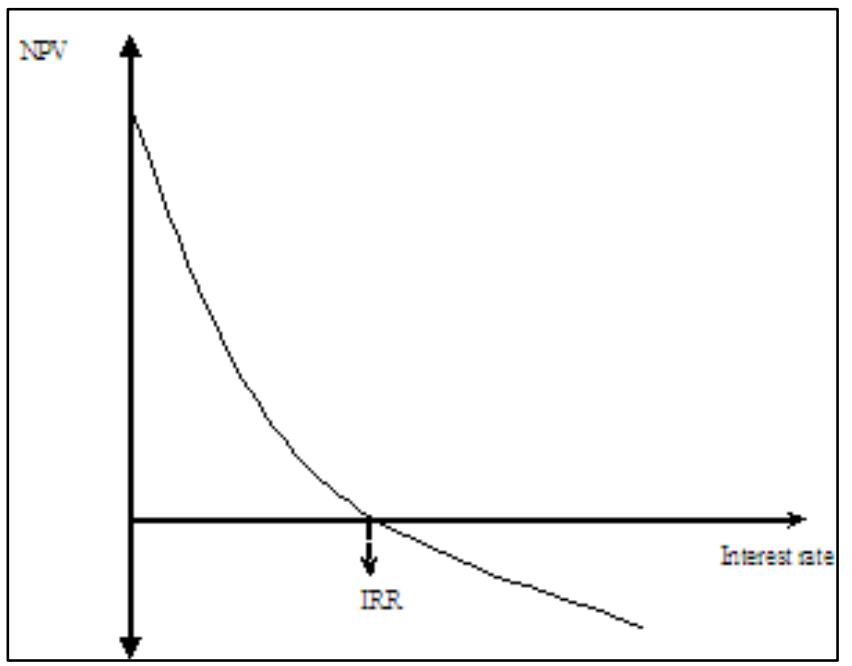

Source: Widely-used illustrations of the relationship (e.g. [3] :254, [6]:79, [46]:329).

Figure 3. The sum of the NPV in the function of interest rate

In order to specify the problem it must be laid down that the curve in Figure 3 is valid for most but not all projects in question. The relationship is only valid for profitable projects with orthodox cash flow pattern. Namely, the NPV is monotonously decreasing, there is only one intersection, and the curve starts with positive sum [31].

The criterion of the monotonously decrease is given by the orthodox cash flow pattern. The function starts from zero percent interest rate. When the required rate of return is zero, then the NPV is calculated by the Formula (1) as follows: 


$$
N P V=\sum_{t=1}^{n} B_{t}-\sum_{t=1}^{n} K_{t}-E_{0}=M_{T} \quad \mid i=0
$$

(The list of symbols is in Appendix No. 8.)

As Formula (2) shows, at zero percent interest rate the NPV is the difference between the nominal value of total revenues and total expenditures including initial investment. This difference can also be considered as an accounting profit summed up in nominal value for the total duration of the project. This gives the conclusion that if no profit is gained at nominal value, the starting point of NPV curve cannot be positive. (Because of this the figure is not valid for projects that do not generate accounting profit.)

The profit calculated at nominal value for the whole duration means the coverage possibilities of the profit requirements. If the profit requirements are not larger than the nominal value of all accounting profits, then the project is acceptable. (This is a logical inherence. The mathematical model proving is in the Appendix no. 3.)

\section{Appendix No. 3 - The economic content of the NPV}

The NPV literature does not deal with economic content clarification. According to my research results, the economic content of the NPV is clear only in case of orthodox cash flow patterns. In this case the NPV is the sum of the surplus profit generated above the required one, discounted for the present time. This is explicable in logical way and demonstrable mathematically as well.

\section{Overall proving}

The economic efficiency of investment projects can be examined correctly by several methods, not only by the published ones. Such a no familiar method can be the return calculation based on following up the return process. At the end of this process the output is the sum of surplus profit (according to all of annual surplus profits is charged with the required rate of return by the end of the duration). The essence of the proof is that the discounting of this surplus profit leads to the NPV.

The first stage of the demonstration describes the return process of the cost of capital. The cost of capital is the sum of the return requirement of the capital face value and its required profit according to the required rate of return.

The amount of the cost of capital not yet returned and the return status is

at the end of Year 1: $-E_{0}(1+i)+H_{1}$

at the end of Year 2: $\left[-E_{0}(1+i)+H_{1}\right](1+i)+H_{2}$

at the end of Year 3:

$$
\left\{\left[-E_{0}(1+i)+H_{1}\right](1+i)+H_{2}\right\}(1+i)+H_{3}
$$

and so on (the list of symbols is in Appendix No. 8). After the return requirement is met, the formula becomes positive. Assuming that the return status at the end of Year 3 already shows the pattern of the development of the process through time, the simplification is introduced.
Eliminating the curly and square brackets:

$$
-E_{0}(1+i)^{3}+H_{1}(1+i)^{2}+H_{2}(1+i)+H_{3}
$$

The numerical definition of the return status inscribed for the end of Year 3 can be applied further for the full duration of the investment:

$$
\begin{aligned}
& -E_{0}(1+i)^{n}+H_{1}(1+i)^{n-1}+H_{2}(1+i)^{n-2}+ \\
& \ldots+H_{n-1}(1+i)+H_{n}
\end{aligned}
$$

In the second stage of the demonstration the surplus profits calculated above to the end of duration is transformed into present value. The three steps of it are: prescribing the discounting formula, fulfilling the discounting process, simplifying the resulted formula.

$$
\begin{gathered}
{\left[-E_{0}(1+i)^{n}+H_{1}(1+i)^{n-1}+H_{2}(1+i)^{n-2}+\right.} \\
\left.\ldots+H_{n-1}(1+i)+H_{n}\right] \frac{1}{(1+i)^{n}} \\
-E_{0}+H_{1} \frac{1}{(1+i)}+H_{2} \frac{1}{(1+i)^{2}}+ \\
\ldots H_{n-1} \frac{1}{(1+i)^{n-1}}+H_{n} \frac{1}{(1+i)^{n}} \\
-E_{0}+\sum_{t=1}^{n} H_{t} \frac{1}{(1+i)^{t}}
\end{gathered}
$$

The Formula (6) has arrived at a transformed variant of basic Formula (1) that is

$$
N P V=-E_{0}+\sum_{t=1}^{n} H_{t} \frac{1}{(1+i)^{t}} \quad \mid H_{t}>0
$$

The proof is complete. The deduction proved that in the case of orthodox cash flow pattern projects the NPV is the discounted amount of the surplus profit generated above the profit requirement according to the discount rate [28].

\section{The profit requirement}

The profit requirement is interpretable on the yearly sums of not returned part of initial investment. The not returned capital can be only within the pay off period (when the NPV is not negative). In the remaining years of the duration there is not profit requirement, therefore the yields of these years are surplus profits.

Calculation mechanism of the profit requirements according to the not returned part of initial investment (after the payback period the sum of the not returned capital is zero):

In the first year:

$$
M_{S 1}=E_{0} i
$$

In the second year:

$$
M_{S 2}=E_{l} i \quad ; \quad \text { where } E_{l}=\left|H_{1}-E_{0} i-E_{0}\right|
$$


In the third year:

$$
M_{S 3}=E_{2} i ; \text { where } E_{2}=\left|H_{2}-E_{1} i-E_{1}\right|
$$

For the $t>1$ year generally:

$$
M_{S t}=E_{t-1} i \text {; where } E_{t-1}=\left|H_{t-1}-E_{t-2} i-E_{t-2}\right|
$$

According to Formula (11) the total profit requirements that arise during the duration of the project can be calculated as follows:

$$
\sum_{t=1}^{n} M_{S t}=\sum_{t=1}^{n} E_{t-1} i \text { where } E_{t-1}=\left|H_{t-1}-E_{t-2} i-E_{t-2}\right|
$$

The calculation of surplus profits and its present value

In the last year of pay-off period the economic content of yield consists of three elements: profit return according to required rate of return, capital return and surplus profit. On this basis Formula (13) describes the calculation of surplus profit concerning the final year of the pay-off period.

$$
H_{z}-\left(E_{z-1} i+E_{z-1}\right)=\Delta H_{z} \mid H_{z}>E_{z-1}(1+i)>0
$$

The yield occurring in the years after the return totally consists of surplus profit. The description of its quantification begins by making formula for the calculation of the annual amounts. The sum of the surplus profit at the end of the first, the second and the third year after the pay-off period:

$$
\begin{gathered}
H_{z+1}+\Delta H_{z}(1+i) \\
H_{z+2}+\left[H_{z+1}+\Delta H_{z}(1+i)\right](1+i) \\
\left.H_{z+3} \neq H_{z+2}+\left[H_{z+1}+\Delta H_{z}(1+i)\right](1+i)\right\}(1+i)
\end{gathered}
$$

Considering the third year's formula, the sum of all of annual surplus profits charged with the interest rate can be calculated by the end of the duration as follows:

$$
F V \Delta M=\sum_{j=1}^{s} H_{z+j}(1+i)^{s-j}+\Delta H_{Z}(1+i)^{s}
$$

Because of the interest rates are charged, Formula (14) contains some false interest income. According to Formula (15) the false interest income falls out during discounting. Surplus profits will be discounted from the year of their occurrence. The present value of the discounted and summed surplus profits is the NPV itself:

$$
N P V=\left[\sum_{j=1}^{s} H_{z+j}(1+i)^{s-j}+\Delta H_{z}(1+i)^{s}\right] \frac{1}{(1+i)^{n}}
$$

After simplification [using $(n=s+z)$ ] there will be a clear formula, according to which the NPV can be reached by discounting and assuming the surplus profits according to the date of occurrence:

$$
N P V=\sum_{j=l}^{s} \frac{H_{z+j}}{(1+i)^{2+j}}+\frac{\Delta H_{z}}{(1+i)^{2}}
$$

Starting from the classical version of the NPV inscription it cannot be seen that only surplus profits remain among the really discounted items [31].

\section{Appendix No. 4 - The ranking problem}

Several decades now is known that the NPVs are not directly comparable. The differences in initial investments, the durations and the rapidity of capital returns may distort the comparability of NPVs [36]. Despite of this, the one-sided recommendation of NPV has not disappeared. There are literary sources for suggestion of certain corrections to eliminate of the distortion effects. These suggestions, however, only concern for the first or the second out of the three distortion effects listed above. (There is no visible pursuit of a complex correction.)

The suggestion for dividing the NPV by the initial investment $\left[\frac{N P V}{E_{0}}\right]$ or using the profitability index $\left[1+\frac{N P V}{E_{0}}\right]$ as a ranking tool, eliminates only the distortion effect of differences in initial investments. For example [6, 2, 49] suggest the profitability index for ranking creating. The paper of Damodaran [8] suggests for this purpose the NPV divided by the initial investment, however, this rate there is named profitability index. By these suggestions only the distortion effect of differences in initial investments is avoided (two of distortion affects are remained).

The suggested equivalent annual average sum of the NPV as a ranking creating tool only eliminates the distortion effect of the differences in duration. The formula of this time-adjusted average is: $q_{n} N P V$. This ranking tool suggestion often appears - mainly in the financial literature in the last three decade (e.g. [15, 39]). The way of quantifying the average is NPV divided by the annuity factor, which in business economics means multiplying by the loan repayment factor. (Business economics always uses the loan repayment factor. The financial literature uses the annuity factor, which is the reciprocal of the previous formula.) This solution only eliminates the distortion effect of the differences in duration (two of them are remained).

Another step could be - although I did not find any suggestions for this in the literature - merging of the above two methods, that is, the equivalent annual average sum of the NPV divided by initial investment, that is $q_{n} \frac{N P V}{E_{0}}$. In the last formula there are eliminated distortion effects of initial investments and durations, however, there is no eliminated the distortion effect of return rapidity. The methodological elaboration of calculating a coefficient which could measure return rapidity seems to be very complicated in this structure. I believe that the calculation of this coefficient is not necessary, but very important to know its essence.

Fundamental cases: a) Return by years is uniform. Than the coefficient is 1 . b) Return is quickly. The larger yields 
arise at the beginning of the duration. In this case the coefficient is bigger, than 1. c) Return is slow. The larger yields arise at the end of the duration. In this case the coefficient is lesser, than 1.

The cleansed formula is as follows:

$$
q_{n} \frac{N P V}{E_{0}} \lambda=(r-i) \varepsilon
$$

The cleansed NPV is a special rate-difference between the factual return rate and the required one. This content is followed from exhibited calculating procedure. The rate-character has appeared when the NPV was divided by initial investment. The matter of rate-difference is following from that, the NPV is a surplus yield. Multiplying this surplus yield rate with the loan repayment factor it transforms the time-adjusted average of NPV rate. The last step is the correction with the coefficient of return rapidity. This way has formed the modified difference between the IRR and the required rate of return. This method cannot lead to the accurate difference of two rates. This is coming from the special cleaning solution in which are mixing the elements of static and dynamic procedures for investment project evaluation. This is indicated by a miscalculation factor [28].

The surplus profitability over the required rate of return (if the required rate is equal for all examined project) will be the highest for the project where the IRR is the highest. Thus the same projects will gain the first, second, etc. place in both rankings. In this correct way there is not methodological superiority.

\section{Appendix No. 5 - Aggregate capital needs}

The calculation method of tied-up capital for the first three years and for the $t>1$ year generally are presented in Equitation (8) - (11). Based on all these, the index number of aggregate capital needs is as follows:

$$
E_{A}=\sum_{t=1}^{n} E_{t-1}
$$

Tied-up capital is a state indicator, and therefore the tied-up capitals of different years cannot be summed up from this aspect. However, in consideration the income-producing potential needs to take into account simultaneously the tied-up capital and tied-up time. The content of the index-number means a capital amount which is tied up for one year. So the measurement unit of this is one unit tied-up capital for one year. According to the calculation method used above a three-year tie-up of one capital unit is equal to three capital units tied up for one year [31].

In the IRR case instead of determining of the yearly amounts of tied up capital and aggregation of it, the estimation can be carried out with a simple dividing two numbers (proving of this is in [32]):

$$
\frac{M_{T}}{r}=E_{A}
$$

\section{Appendix No. 6 - The profit requirement of debt}

The total return requirement for a given year is as follows:

$$
\left[\begin{array}{l}
\text { SALES } \\
\text { REVENUE }
\end{array}\right] \geq\left(\begin{array}{l}
\text { VALUE OF } \\
\text { USED UP } \\
\text { RESOURCES }
\end{array}\right]+\left(\begin{array}{l}
\text { CAPITAL YIELD } \\
\text { REQUIREMENT } \\
\text { ABOVE } \\
\text { DEPRECIATION }
\end{array}\right)
$$

When microeconomics defines opportunity cost regarding investment opportunities, the capital is an unstructured amount and the unstructured opportunity cost concern to the whole capital. In accordance with this principle, the capital yield requirement above depreciation is the operating profit requirement. This consists of two main parts: the price of capital usage and the risk premium requirement. The required rate of return also consists two parts.

$$
i=i_{D}+i_{V}
$$

For the sake of simplification the price of capital use is calculated on the basis of the risk-free rate realized on public securities. In practice however, the price for use of debt capital differs from the risk-free rate. The lender and borrower - because of the creditors are secondary risk holders - share the risk premium requirement. This sharing does not affect the required rate of return (because of the opportunity cost is unchanged). This model treats the internal structure of required rate of return as a fixed one. The fixed structure can be dissolved. (Lack of this simplification the required rate of return would be structured by three parts: risk-free rate; risk premium charged by the creditor; and the risk premium requirement above the mentioned two parts.)

In the structure of capital yield requirement above depreciation

- $\quad i_{V}$ always means profit requirement and

- $i_{D}$ means profit requirement when it concerns on equity and cost return requirement when it concerns on debt.

The calculation of capital yield requirement above depreciation in a given year is as follows:

$$
E_{D} i_{D}+M \geq E_{D} i_{D}+E_{D} i_{V}+E_{S} i
$$

According to Formula (21) the sum of profit requirement in a given year

$$
M_{S}=E_{D} i_{V}+E_{S} i
$$

The $\left[i_{V} E_{D}\right]$ element of Formula (21) and (22) is missing from finance return requirement conception. (More details are in [19].)

\section{Appendix No. 7 - The distortion-free rate of capital yield}

The condition of constructing the distortion-free rate of capital yield is that the index can be deduced from the total return requirement. (The total return requirement is described in Appendix 6.) Below two distortion-free rate 
constructions are presented.

The capital yield is the sum of profit and interest payments

$$
\begin{gathered}
E_{D} i_{D}+M \geq E_{D} i_{D}+E_{D} i_{V}+E_{S} i_{D}+E_{S} i_{V} \\
E_{D} i_{D}+M \geq E\left(i_{D}+i_{V}\right) \\
\frac{E_{D} i_{D}+M}{E} \geq i
\end{gathered}
$$

The capital yield is the difference of profit and "price" of equity usage

The startup point is as follows: $M-E_{S} i_{D}=M_{V}$

From Formula (23):

$$
\begin{gathered}
M_{V} \geq E_{D} i_{V}+E_{S} i_{V} \\
\frac{M_{V}}{E} \geq i_{V}
\end{gathered}
$$

(More details are in [18].)

\section{Appendix No. 8 - List of symbols}

$\mathrm{AC}=$ average cost,

$\mathrm{B}_{\mathrm{t}}=$ sales revenues in year $\mathrm{t}$,

$\mathrm{E}=$ sum of capital in a given year,

$\mathrm{E}_{0}=$ initial investment (the investment sum is occurring in the zero point of time),

$\mathrm{E}_{\mathrm{A}}=$ aggregate capital needs,

$E_{D}=$ sum of debt in a given year,

$\mathrm{E}_{\mathrm{S}}=$ sum of equity in a given year,

$E_{t}=$ the not returned part of initial investment at the end of year $\mathrm{t}$,

$\mathrm{FV} \Delta \mathrm{M}=$ the sum of the surplus profit charged with interest rate at the end of the duration,

$\mathrm{H}_{\mathrm{t}}=$ the difference between sales revenues and expenditures in year $\mathrm{t}$ (where $\mathrm{t}>0$ and $\mathrm{H}_{\mathrm{t}}>0$ for orthodox cash flow pattern projects),

$\mathrm{i}=$ required rate of return,

$i_{D}=$ price of capital usage (per one unit of capital),

$\mathrm{i}_{\mathrm{V}}=$ required risk premium rate,

$j=$ the ordinal number of the years of operating period after the pay-off,

$\mathrm{K}_{\mathrm{t}}=$ expenditures in year $\mathrm{t}$,

$\mathrm{M}=$ the profit sum in a given year,

$\mathrm{MC}=$ marginal cost,

$\mathrm{M}_{\mathrm{S}}=$ the sum of profit requirement in a given year,

$\mathrm{M}_{\mathrm{St}}=$ the profit requirement in year $\mathrm{t}$ according to the not returned part of capital and required rate of return,

$\mathrm{M}_{\mathrm{T}}=$ total accounting profit that is the difference of the nominal value of total revenues and total expenditures including initial investment arising during the whole duration of the project,

$\mathrm{M}_{\mathrm{V}}=$ sum of the risk premium in a given year,

$\mathrm{n}=$ duration of the project $(\mathrm{z}+\mathrm{s})$,

$\mathrm{q}=$ the loan repayment factor, within the required rate of return and duration of the project,

$r=$ internal rate of return (IRR),

$\mathrm{s}=$ the number of years of the operating period after the pay-off $(\mathrm{s}=\mathrm{n}-\mathrm{z})$, $\mathrm{t}=$ serial number of years,

$\mathrm{TC}=$ total cost,

$\mathrm{z}=$ number of years of the pay-off period (including the

last commenced year),

$\Delta \mathrm{H}_{\mathrm{z}}=$ sum of the surplus profit in the last commenced year of pay-off period,

$\lambda=$ coefficient of payback rapidity,

$\varepsilon=$ miscalculation factor.

\section{REFERENCES}

[1] Adelberg, A. H., Fabozzi, F. J. C Polimeni, R. S. (1986): Cost Accounting. Concepts and applications for managerial decision making. McGraw-Hill Book Company.

[2] Albrecht, W., Stice, J., Stice, E. \& Monte Swain, M. (2007): Accounting: Concepts and Applications. Cengage Learning Thomson South-Western.

[3] Arnold, J. \& Hope, T. (1990): Accounting for Management Decisions. Prentice Hall International (UK) Ltd.

[4] Baker, H. K. \& Powell, G. E. (2005): Understanding Financial Management: A Practical Guide. John Wiley \& Sons. USA, UK, Australia.

[5] Boehm-Bawerk, E.V. (1889): Positive Theorie des Kapitales. Jena: Fisher.

[6] Brealey, R. A. \& Myers, S. C. (1988): Principles of Corporate Finance. (Third edition.) McGraw-Hill Publishing Company, New York, St. Louis, San Francisco etc.

[7] Crundwell, F. K. (2008): Finance for Engineers. Evaluation and Funding of Capital Projects. Springer, London.

[8] Damodaran, A. (2010): Applied Corporate Finance. John Wiley \& Sons Inc. Hoboken.

[9] Du Plessis, A. P., Du Toit, C. M. \& Nortje, J. D. (1981): Fundamental of Business Economics. Butterworths \& Co (SA) (PTY) Ltd.

[10] Ekelund, R. B. Jr. - Tollison, R. D. (1986): Economics. Little, Brown and Company. Boston, Toronto.

[11] Fernández, P. (2011): WACC: Definition, Misconceptions and Errors. IESE Business School - University of Navarra. Working Paper. WP-914. (DI-0914-E).

[12] Fisher, I. (1930): The Theory of Interest. Macmillan, New York.

[13] Garrison, R. H. (1988): Managerial Accounting. Concepts for Planning, Control, Decision Making. Business Publications, Inc. Plano, Texas.

[14] Heitger, L. E. \& Matulich, S. (1985): Cost Accounting. McGraw-Hill Book Company. New York.

[15] Helfert, E. A. (1991): Techniques of Financial Analysis. Business One Irwin. USA.

[16] Hornby, W., Gammie, B. \&Wall, S. (2001): Business Economics. Second Edition, Pearson Education, Harlow.

[17] Illés, M. (1985): Gazdasági kalkuláció és tisztánlátás (Product 
cost calculation and perspicacity). Közgazdasági Szemle,Vol. XXXII. No. 3 pp. 320-343.

[18] Illés, M. (2002): Vezetői gazdaságtan (Managerial Economics.) Kossuth Könyvkiadó, Budapest.

[19] Illés, M. (2004): A vállalati adósság értékelése a gazdaságossági számításokban (Treatment of Debt at the Economic Calculations). Gazdasági szerkezet és versenyképesség az EU csatlakozás után: a VIII. Ipar- és Vállalatgazdasági Konferencia előadásai. MTA Ipar- és Vállalatgazdasági Bizottság, pp. 454-459.

[20] Illés, M. (2005): A folyó költségek fedezeti pontja és az üzembezárási pont (Break-even Point at the Out of Pocket Costs and the Shutdown Point). In: Szintay István, Szilágyiné Fülöp Erika (eds) Tanulmányok Czabán János tiszteletére. Miskolc: Miskolci Egyetem Gazdaságtudományi Kar, 2005. pp. 251-266.

[21] Illés, M. (2005): A vállalati gazdaságtan alapvető tudományos kérdései (Basic Scientific Questions of Business Economics). In: Ünnepi tanulmányok Czabán János professzor 70. születésnapjára. Miskolci Egyetem Gazdaságtudományi Kar, pp. $20-30$.

[22] Illés, M. (2007): A hitelkamat, mint “adópajzs" (Interest Payment as a "Tax Shield"). In: VII. Regionális Tanácsadási Konferencia. pp. 1-12.

[23] Illés, M. (2007): Az „éves költség-egyenértékes“ gazdasági tartalma és alkalmazási kérdései (Economic Content and Application Questions of the "Equivalent Annual Cost"). In: Miskolci Egyetem - Gazdaságtudományi Kar. VI. Nemzetközi Konferencia a közgazdász képzés megkezdésének 20 éves évfordulója alkalmából, Vol. I, pp. 116-125.

[24] Illés, M. (2007): Scientific Problems of Modern Approach of Net Present Value. Theory, Methodology, Practice: Club of Economics in Miskolc. Vol. 4. No. 1, pp. 29-35.

[25] Illés, M. (2008): A gazdálkodástudományi eredmények gyakorlati hasznosíthatóságának néhány problémája (Some Problems of the Practical Usability of Business Economics Results). In: A gazdasági környezet és a vállalati stratégiák: a IX. Ipar- és Vállalatgazdasági Konferencia Előadásai. MTA IX. Osztály Ipar- és Vállalatgazdasági Bizottsága, pp. 73-82.

[26] Illés, M. (2009): Technológiai változatok gazdaságossági szempontú összehasonlítása (Economic Comparison of Technological Variants). In: Miskolci Egyetem Gazdaságtudományi Kar VII. Nemzetközi Konferencia: Vol. I-II. Miskolci Egyetem, Gazdaságtudományi Kar, pp. 86-93.

[27] Illés, M. (2011): A fedezeti pont a mikroökonómiában és a vállalati gazdaságtanban (Break-Even Point in Microeconomics and Business Economics). In: Jubileumi tanulmánykötet Nagy Aladár professzor 70. születésnapjára. Miskolci Egyetem Gazdaságtudományi Kar, pp. 113-126.

[28] Illés, M. (2012): Transforming The Net Present Value for a Comparable One. Theory, Methodology, Practice: Club of Economics in Miskolc. Vol. 8. No. 1. pp. 24-32.

[29] Illés, M. (2012): Links Between Net Present Value and Shareholder Value from a Business Economics Perspective. Theory, Methodology, Practice: Club of Economics in Miskolc. Vol. 8. No. 2. pp. 31-36.
[30] Illés, M. (2013): A gyakorlat szempontjából felmerülő vállalatgazdaságtani problémák. (Business Economics Problems in Practical Point of View). In: Karlovitz János Tibor (Ed.) Ekonomické štúdie - teória a prax: Gazdasági tanulmányok - elmélet és gyakorlat. Komárno: International Research Institute. pp. 7-13.

[31] Illés, M. (2014): Fisher's Rate and Aggregate Capital Needs in Investment Decisions. Theory, Methodology, Practice: Club of Economics in Miskolc. 2014. Vol. 10. No. 1. pp. 21-32.

[32] Illés, M. (2015): Az aggregált tőkeigény gyors becslésének lehetősége a belső kamatláb esetén (Possibility for a Quick Estimation of Aggregate Capital Needs in Case of Internal Rate of Return). In: "Mérleg és Kihívások" IX. Nemzetközi Tudományos Konferencia. Miskolci Egyetem Gazdaságtudományi Kar, Miskolc, pp. 575-586.

[33] Illés, M. (2016): The Real Reinvestment Rate Assumption as a Hidden Pitfall. Theory Methodology Practice. Club of Economics in Miskolc. Volume 12, Number 1, pp. 47-60. http://dx.doi.org/10.18096/TMP.2016.01.06 47

[34] Illés, M. (2016): Vállalati gazdaságtan (Business Economics). Miskolci Egyetemi Kiadó, Miskolc.

[35] Kaplan, R. S. \& Atkinson, A. A (1998): Advanced Managerial Accounting. Third Edition. Prentice Hall.

[36] Keane, S. M. (1975) Investment selection criteria: an examination of the theory of the internal rate of return and of the investment discount rate under conditions of uncertainty. $\mathrm{PhD}$ thesis. University of Glasgow.

[37] Keynes, J.M. (1936): The General Theory of Employment Interest and Money, Harcourt, Brace \& Company, New York,

[38] Laux, J. (2011): Topics in Finance Part VI - Capital Budgeting. American Journal of Business Education - Volume 4, Number 7 pp. 29-38.

[39] Lee, A. C., Lee, J. C. \& Lee, C. F. (2009): Financial Analysis, Planning, and Forecasting: Theory and Application. World Scientific Publishing Co. Pte. Ltd.

[40] Moriarity, S. \& Allen, C. P. (1987): Cost Accounting. Harper \& Row, Publishers, Inc. New York.

[41] Samuelson, P. A. \& Nordhaus, W. D (1985): Economics. Twelfth Edition. McGraw-Hill Book Company, New York.

[42] Schmalen, H. (2002): Általános üzleti gazdaságtan. (General Business Economics) Axel-Springer Budapest Kiadó.

[43] Soutwick, L. Jr. (1985): Managerial Economics. Business Publications, Inc. Plano, Texas.

[44] Spencer, M. H. \& Siegelman, L. (1959): Managerial Economics. Decision Making and Forward Planning. Richard D. Irwin, Inc., Homewood, Illinois, 1959.

[45] Starr, M. K. (1989): Managing Production and Operations. Prentice Hall, Englewood Cliffs, New Jersey.

[46] Van Horne, J. C. \& Wachowicz, J. M., Jr. (2008): Fundamentals of Financial Management. Pearson Education Limited. Harlow.

[47] Volkman D. A. (1997): A consistent yield-based capital budgeting method. Journal of Financial and Strategic Decisions. Volume 10 Number 3, pp. 75-88. 
[48] Walker, J. S. - Check, H. F., Jr. - Randall, K. L. (2011): Does the Internal Rate of Return Calculation Require a Reinvestment Rate Assumption? - There Is Still No Consensus. West Chester University: Pennsylvania Economic Association Proceedings Annual Conference, June 3-5, 2010. pp. 118-130.
[49] Watson, D. \& Head, A. (2009): Corporate Finance: Principles and Practice. Pearson Education Limited, Harlow.

[50] Woods J.C. \& Randall M. R. (1989): The Net Present Value of Future Investment Opportunities: Its Impact on Shareholder Wealth and Implications for Capital Budgeting Theory. Financial Management, Vol. 18, No. 2, pp. 85-91. 